\title{
Doing public pastoral care through church-driven development in Africa: Reflection on church and community mobilisation process approach in Lesotho
}

Author:
Vhumani Magezi ${ }^{1}$
Affiliation:
${ }^{1}$ School of Christian Ministry
and Leadership and URT,
Faculty of Theology,
North-West University,
Potchefstroom, South Africa
Corresponding author:
Vhumani Magezi,
Vhumani.Magezi@nwu.ac.za
Dates:
Received: 18 Apr. 2019
Accepted: 05 Sept. 2019
Published: 29 Nov. 2019
How to cite this article:
Magezi, V., 2019, 'Doing public
pastoral care through
church-driven development in
Africa: Reflection on church
and community mobilisation
process approach in Lesotho',
prodine.
HTS Teologiese Studies/
Theological Studies $75(4)$,
a5501. https://doi.org/10.
4102/hts.v75i4.5501
Copyright:
C 2019. The Authors.
Licensee: AOSIS. This work
is licensed under the
Creative Commons
Attribution License.

African communities face various challenges that require different sectors' interventions to be effectively addressed. Churches as key community structures in Africa along with people experience these life challenges. The situation prompts churches to continually re-examine their role in communities to develop relevant responses that are deeply rooted in Christian approaches and heritage. Pastoral care as a community frontline ministry is expected to intervene practically to address people's holistic needs. However, the questions that emerge are the following: how can pastoral care practically be performed in a manner that it performs a public community caring role? How can public pastoral care be practically implemented? What models can be employed in providing public pastoral care? This article considers how pastoral care can be practically performed at the intersection of public theology and community development. Pastoral care performed at this intersection is termed public pastoral care. The article discusses and notes the 'murky' terrain and 'apparent confusion' on the notion of public pastoral care. Furthermore, it employs a church and community mobilisation process (CCMP) case study to progress beyond theoretical discussion to examine how public pastoral care can be operationalised in real-life situations. In doing so, it discerns the possibilities and challenges of positioning pastoral care to address public issues.

Keywords: Public pastoral care; Church and community mobilisation process; Public theology; Community development; Pastoral care; Church-driven development; Congregational pastoral care.

\section{Introduction}

The need for theology to engage with wider social issues has given rise to public theology (Kim 2017:40-60).

Connected to public theology development are developments in public practical theology (Dreyer 2004, 2011; Dreyer \& Pieterse 2010; Osmer \& Schweitzer 2003) and public pastoral care (Louw 2014; McClure 2012; Miller-McLemore 2004, 2005, 2018; Ramsay 2004, 2014). McClure (2012:275) describes theology as 'New Horizons in Pastoral Care' that rightly summarises the focus of pastoral care on public issues. These new horizons entail a shift from (1) pastoral care for an individual by an ordained professional to a model of care for the community and its members and by the community and its members, (2) the development of pastoral care as a public theology and (3) strategic participation in people's lives rather than personal insight as the final goal. These observations are shared by other leading pastoral care theologians (Louw 2014; Miller-McLemore 2018; Ramsay 2014). Despite the recognition of the need for pastoral care to address broader social issues, the vexing questions and issues that currently remain somewhat like a black box or lacking clarity are the following: how does public pastoral care look like? How should public pastoral care be practically conceptualised? How can public pastoral care be done? What is pastoral about engaging in social issues?

To contribute towards shedding light on and responding to the above questions from an African context, firstly, this article highlights the diverse challenges (Africa contextual synopsis) that necessitate a need for public pastoral care; secondly, it conceptualises the notion of public pastoral care by grounding it within a real-life community development context; and, thirdly, it presents a practical case study of church community mobilisation process as a pragmatic real-life effort

Note: Faith-Based Organisations, sub-edited by Nadine Bouwers du Toit (Stellenbosch University), Vhumani Magezi (North-West University) and Elisabet le Roux (Stellenbosch University). 
towards implementing a Christian ministry that can be deemed public pastoral care.

The structure of the article is as follows: firstly, it problematises the issues and then provides a theoretical framework by conceptualising the notion of public pastoral care. Next, the article illustrates how practical Christian ministry that can be described as a public pastoral care can be performed in an organic, complex and fluid real-life situation.

It is noteworthy that the public pastoral care practical ministry (i.e. church community mobilisation process) was not implemented necessarily as an academic research project but a church programme. Whilst the study was in the form of a development programme, it justifiably falls within the category of implementation research. Peters et al. (2014:1) observed that implementation research is a growing but not well understood field'. Woolsey and Biebel (2007:3) describe implementation research as 'a black box, providing information about the journey from research theory to actual practice. Implementation studies examine issues of design, administration and operation by tracking day-to-day "real world" events'. The project merits analysis from a practical inquiry perspective as an implementation research. A practical inquiry approach is rooted in pragmatist philosophy. It aims at generating knowledge for local people as well as general practice. Göran (n.d) explains that whilst a practical inquiry approach shares similarities with action research, there are differences. The purpose of a practical inquiry is to contribute to general practical knowledge through empirical study on practical matters in local practices. Stevenson (2005) distinguishes between practical inquiry and positivist inquiry approaches by noting that positivist approaches produce theories that are detached from the practical situations of people and lack relevancy to everyday practice, whilst practical inquiry generates practical knowledge in the fluidity and flux of practical daily realities. He adds that practical theory is judged in terms of whether it helps people to 'go on' with their lives. Thus, even though the project was not necessarily an academic study per se, its implementation conformed to a practical inquiry approach.

\section{Need for public pastoral care - Issue problematisation}

The challenges faced by African communities are numerous. The churches, like other social institutions, are expected to contribute to addressing some of the problems. Two issues, namely, corruption and governance, can be highlighted to illustrate the point. The Transparency International (2018) Corruption Perceptions Index report revealed that the majority of African countries generally have high levels of corruption. Regarding governance, the Mo Ibrahim Foundation (2018), which is an African foundation established in 2006 to focus on the critical importance of governance and leadership in Africa, reported that:

African governments have failed to translate economic growth into improved sustainable economic opportunity for their citizens. Since 2008 the African average score for Sustainable
Economic Opportunity has increased by 0.1 point, an equivalent of only $0.2 \%$, despite a continental increase in GDP of nearly $40 \%$ over the same period. There has been virtually no progress in creating Sustainable Economic Opportunity, meaning it remains the Index's worst performing and slowest improving category. There is also no strong relationship between the size of a country's economy and its performance in Sustainable Economic Opportunity. In 2017, four of the ten countries with the highest GDP on the continent still scored below the African average score for Sustainable Economic Opportunity and sit in the lower half of the rankings. (pp. 17-18)

It is understandable, therefore, that during the Papal visit to Africa in 2015, Pope Francis discouraged corruption, discrimination, inequality, violence and pollution (Bader 2015). The concerns echoed by the Pope have also been expressed by other Christian leaders in Africa. The concern of the churches and theological leadership on social and public challenges in African communities was summarised by the Network for African Congregational Theology (NetACT), a network of theological institutions in sub-Saharan Africa that was created to assist in preparing leaders for missional congregations through networking and sharing of resources.

The NetACT launched a research book project in 2018 entitled 'African Public Theology'. The research intends to address 'the endemic corruption and lack of principled Christian leadership in our continent' (NetACT 2018:1).

The challenge of doing theology in African continent is manifold and it seems to be pulled in all directions.

African theology that emerged as a reaction to the early Western missionaries and some Western theologians who advocated for the elimination of all that had to do with preChristian African tradition (Bediako 1997:426-444) has lost significant relevance. At the same time, Black Theology in Southern Africa, with its focus on liberation from oppression and injustices such as racism and economic exclusion that African Americans and black people in South Africa experienced (Chimhanda 2010:434-445), has declined in influence. Noting the limitation of these theologies, VillaVicencio (1992) and Mugambi $(1995,2003)$ advocated for a Reconstruction theology that holistically addresses African problems of racism, colonialism, neo-colonialism, bad governance, corruption and poor leadership, issues that have caused destruction in many African countries and societies.

In Villa-Vicencio's (1992) view, theology of reconstruction integrates all issues that affect humanity. Mugambi (1995:7-9) comprehensively defines what he means by theology of reconstruction, by stating that it is an all-encompassing theology that affects all aspects of life. Different from these African theological approaches that grappled with issues contextually and theologically, there is a brand of theology that has emerged in Africa, which lacks deep reflection. This brand of theology seems aligned with the wealth and prosperity movement.

Nwachuku (2014) observed that Christianity and theology in Africa are caught in a quandary of fast-growing African 
Independent Churches (AICs). Nwachuku (2014) in describing this theology concluded that the greatest challenge in Africa today is no longer the referencing and importing of Western practices (as was the case during missionary era), but how to bring personal theologies of daily life that are often informed by subjective experiences into a meaningful scholarly engagement. Magezi (2016) added that the theology focusses on praxis with little reflection.

Despite the lack of theological reflection, at praxis level, the new brand of theology addresses practical challenges by ensuring that Christian leaders engage with people's life challenges. People's life issues are complex, which call for holistic approaches when engaging in real-life issues. Pastoral ministry as a frontline ministry of the church inevitably bears the burden of dealing with people both at practical and spiritual levels. Pastors assume various roles such as counsellors, community leaders, public officials, and so on. Thus, pastors cannot adopt a single approach in interfacing with communities but rather adopt multiple approaches in an eclectic manner. However, the question that emerges is the following: in view of the diverse social challenges experienced by people and the diverse expectations they have from the pastor, is theology and pastoral ministry a community silver bullet that addresses all community challenges?

Louw (2014) advised that theology must be humanised and democratised and public theology with the focus on ethical questions and public issues has become a major focus area of research in theology. McClure (2012:276) added that pastoral care as public practice entails developing practices from the ground. It is about engaging the real issues that people struggle with on a daily basis in society. Pastoral care in Africa, therefore, should adopt an intentionally public role. Christian ministry and theology should engage in public theology by tackling issues of the society. Thus, resonating with the notion of Reconstruction theology and its comprehensive agenda, NetACT's (2018:1) 'African Public Theology' project covers a broad range of issues including leadership, local community issues, poverty, education, science, health, environment, work, democracy, citizenship, etc. Whilst this broadness and shift to public theology exacerbates the situation of the proverbial 'wide river' (i.e. church with large membership) that is 'theologically shallow' in Africa, it reflects complexity and calls for a response.

There is a need for transformation of people's lives. People and community transformation entails facilitating people's progress and development. Church care, therefore, means human (i.e. soul-nephesh) care, which in Christian ministry is called holistic ministry. This integrated approach of doing Christian ministry is denoted by the terms such as 'integral mission', 'holistic mission or ministry', 'Christian development', 'transformation' or 'church-driven development' (Chester 2004:63; Magezi \& Mutowa 2018:124).

Notwithstanding the recognition that churches are playing a critical holistic ministerial role, there are some notable gaps. Magezi (2018:1-5) highlighted some of the grey areas by posing the following questions: how does integral mission, which is Christian development in our case, practically look like? What is the role of local churches and denominations in integral mission, particularly in development initiatives? Magezi (2017) added that churches should not be viewed as instruments and vehicles or channels for development by virtue of their proximity to the community but rather as possessing a unique differentiating Christian transformation framework than other development organisations. Sugden (2010:31-36) advised that the utility of churches in development should not be for pragmatic reasons. Therefore, Mati (2013:2) lamented that churches are the most prominent manifestations of civil society and community organisations in Africa responsible for holistic ministry interventions, but they lack adequate social scientific analysis. The lack of scientific analysis is particularly evident in church-driven development initiatives that are examined in practical reallife situations. It is important to discern the models of integral mission that emerge from practical implementation of programmes in the context of church praxis. Peters et al. (2014:1) called such examination of practical interventions a kind of implementation research which is a growing but not well-understood field. Woolsey and Biebel (2007:3) described implementation research as 'a black box, providing information about the journey from research theory to actual practice. Implementation studies examine issues of design, administration, and operation by tracking day-to-day, "real world" events'. Peters et al. (2014:3) suggest that, amongst other things, the function of implementation research is to identify and describe the implementation dynamics and the practical models that emerge in a given real-life context.

In view of the above, the questions that I pose to guide this research are as follows: what possible model of implementing practical holistic ministry could be employed in an effort to make Christian ministry engage in and address complex public social issues? How could such an approach fulfil Christian ministry in a manner that intersects pastoral care, public theology and community development on the front of people's lives to address their complex challenges? To respond to the above questions, this article reflects on the notion of public pastoral care and uses a case study of church and community mobilisation process (CCMP) in Lesotho to discern how public pastoral care could be applied in real-life situation. At a theoretical level, the study contributes to an understanding of practical utilisation and leverage of churches in society to address complex public issues as a public pastoral care approach.

\section{Public pastoral care conceptualisation within development}

The link between public theology and pastoral care is easily discernible. People's struggles and challenges in life cause immense pain, disorientation and suffering (Louw 2014). Therefore, pastoral care is called upon to intervene. At the same time, when social and community challenges, such as poverty, gender-based violence, and abuse, are experienced, 
it is unavoidable to ask the questions: what should churches do? Why should churches intervene, particularly pastors? The responses to these questions are arguably provided by public theology. Levesque (2014:38) observed that public theology has been practised by the vanguard of individuals calling for a reimagining of how Christians engage with the world around them. The world surrounding Christians like any other person was aptly described by the leading pastoral care theologian Miller-McLemore (2018:318) as a 'human web'. The world that an individual Christian and the institutional church exists in is diverse and complex. Therefore, public theology is about being a church in the world with its complexities.

Mannion (2009:122) noted that public theology is a shorthand for church 'in' the world. It is about lived Christianity where an individual interacts with social, political and practical issues and challenges. Mannion (2009:151) rightly maintained that public theology is about public ecclesiology. It is concerned with ecclesiological questions of the churches' relevance to issues affecting people today. Therefore, public ecclesiology, pastoral care and diakonia intersect, which clearly indicates a public pastoral role for the church.

Kim (2017:40) noted that the term 'public theology' or 'public church' was introduced into theological circles by Martin Martyr and Robert Bellah in the 1970s. He defined public theology 'as critical, reflective and reasoned engagement of theology in society to bring the kingdom of God, which is for the sake of the poor and marginalised' (Kim 2017:40). Kim (2017:40) added that public theology is a theology that 'arises out of the engagement of theology in the spheres of politics and economics, which was then expanded to civil societies and other areas of the public life'.

Public theology became popular in recent years as evidenced by the establishment of the Global Network for Public Theology (GNPT) and other developments including the International Journal of Public Theology and a proliferation of public theology centres (Kim 2017:40). Notwithstanding the impact of the recent developments in popularising the discipline, public theology has been practised over the centuries. It has been practised throughout Christian history. Churches have been engaging with the wider society and political institutions both as minority communities and as dominant bodies. Kim (2017:44-60) described the public theological approaches during the periods of St Augustine, Reformation, in Catholic teaching, in Ecumenical developments in the 20th century Europe, USA and Global South (Latin America, Asia and South Africa). Kim (2017:61) concluded his analysis by noting the current public theology approaches. Amongst these approaches are two key approaches that are relevant to pastoral care. The first approach is the interplay between theory and practice between theology and the church and practical theological disciplines. The second approach is the examination of particular issues in different sociopolitical contexts to develop methodologies for contextual public theology. Both these approaches directly apply to public pastoral care approach, particularly to our discussion of church-driven development in Africa. This is critical because it contributes to what Kim (2017:61-62) noted as the fourth gap in the current public theological conceptualisations of supporting minorities, the poor, marginalised and the voiceless, which needs priority.

Importantly, public theology is a corrective of irrelevant and aloof theology to the public issues. Day and Kim (2017:2) stated that public theology is a corrective of individualistic, parochial and inaccessible theology that does not engage with the publics. Tracy (1981:5) described the three publics that should be engaged by theology as society, the academy and the church. The spheres of society include government, economic structures and civil society. The academy is also a target because it cannot be separated from society by being in an ivory tower. The academy should engage with social issues as seen in the liberation theology movement. The church is also directly targeted as a community of moral and religious discourse. The church has to influence and embody the ethical and moral standards expected by society. Methodologically, public theological approaches challenge and refute the bipolarity and division of secular and sacred, it is interdisciplinary and dialogical.

Public theological literature tends to speak about reflection (Day \& Kim 2017:18), which conjures up the idea of nonaction or could be misconstrued that way. On the contrary, public theology entails action. Day and Kim (2017:17) observed that the final distinguishing mark of public theology is that it is not only expressed in publications but also performed in action. In public theology, there is no boundary between action and reflection and there is not a one-way movement from theological reflection that is applied in a social context. Rather, the two are interactive. The public theology approach resonates with practical theology. Pastoral care as a practical theology discipline is anchored into such a dialectic and spiral approach.

Pastoral care as cura animarum [cure of souls] is shifting from individual intrapsychic focus to addressing public issues (Louw 2014; McClure 2012; Miller-McLemore 2004, 2005, 2018; Ramsay 2004, 2014). Miller-McLemore (2018:312) highlighted three trends behind this shift. These are the interest in congregational studies, the call for a new public theology and the rise of liberation movements. Therefore, Miller-McLemore (2018:313) advised that pastoral care should shift to social ethic that is relevant to public problems. She stated that pastoral care should socialise believers to particular understandings of church and social ethic of public care because religion has public consequences. For instance, from the perspective of liberation pastoral care approach, pastoral care is for society itself (Moseley 1990).

But what does it mean to be a public pastor who provides public pastoral care? Vanhoozer and Strachan (2015:21) explained that the pastor as a public theologian is called to point or direct people, to nurture and facilitate church people to live their true identity both within and without. The pastor-public theologian helps people to understand their 
context, which entails exegeting their context theologically and biblically in order to help them to respond to the situation in an imaginative and innovative way in a Christlike manner. Thus, a public pastor is an organic intellectual of the body of Christ who intersects public and community issues and engages them from a Christian perspective. This means that a pastor cannot be private and individualistic but has to be public. It is for this reason and others that pastoral care has expanded its theory and practice to interpret and engage the larger world. It has to address the living documents (individual humans) within a complex human web (Graham 2000:9; Miller-McLemore 2018:313). To do that, Graham (2000:12) argued that pastoral care needs to develop public pastoral strategies for healing, sustaining, guiding and liberating individuals, cultures and natural order. Ashby (2000:21) opines that pastoral theology is quiet as a dialogue partner with public theology.

Shifting pastoral care to public pastoral care entails developing practical ways of healing aimed at the public space (Leslie 2008:21). This means that pastoral care addresses the three publics of society, academic and the church. Currently, the church and academic pastoral discussion is happening, but focus on society is very little.

Pastoral care should transform people's daily lives. However, the challenge is: how can such a transformation be done? Leslie (2008:80-83) noted that whilst there is a shift of pastoral care to the public space, many pastoral care providers do not feel equipped to work in the public or rather they do not feel theologically equipped to do so. Understandably, moving into the public space requires fundamental work of reflection and theorising. It calls for translation of language to suit the public space. Dreyer (2011:3) and Dreyer and Pieterse (2010:6) contended that because theology in the public space manifests in multifarious ways, it is important to assist it with language. De Gruchy (2007:39) advises that public theology needs to use a common language that is understandable by people outside the Christian tradition. Koopman (2012:16) equally expressed the need for a language for public discourse. De Villiers (2005:530) calls this 'translation of the Christian vision to a wider society'. Therefore, Koppel (2015) noted that:

Practising public theology asks that pastoral care practitioners and theologians take seriously and engage mindfully with issues that concern groups of people and whole populations, rather than individual persons in isolation. Framing pastoral care ministries, education, and institutions through this larger social lens helps theorists and practitioners to refine methods and purposes for our common work. (p. 151).

However, the fundamental question is, for instance, 'how can pastoral care language such as God images be translated into public language?'

Notably, in the efforts to position pastoral care in the public space, there is confusion on the language of public pastoral care. Leslie (2008:96-97) experienced that at one level public pastoral care appears to be practical theology and at times sounds like public theology. Therefore, she clarifies that it is pastoral care, not practical theology or public theology, because it is the practice of pastoral care in a public setting. However, a further complication of practising pastoral care in the public space is that the pastoral caregiver should be competent in handling diverse public issues. Public pastoral care entails committing and striving to be experts in many areas in order for pastors to meaningfully engage in the public space. For instance, a pastor may be required to understand business management, economics, community development, international development, politics and many other disciplines in addition to his or her theological understanding. It calls for multiplicity of expertise in areas such as use of the Bible, how to do community mapping, how to be a community negotiator, how to be a community development agent, how to engage with politicians, how to be a family negotiator and many others.

It calls for what I would call an 'expert generalist' to facilitate holistic pastoral care within the complex web of life. But how is this possible? How can a pastor be expected to perform such a 'superhuman' role? Greider (2008) asked this question of the ever-expanding scope of pastoral care and suggests that pastoral caregivers should make strategic decisions about where to focus depending on their social context and demand. She suggests that pastoral care providers should be articulated about their limits and how they triage (Greider 2008:54). In my case, the triaging is pastoral care in community development context.

Thus, our aim is to employ a case study to illustrate the complexity and organic practical approaches of doing public pastoral care. The case study entails a churchdriven development intervention called CCMP in Lesotho by the Anglican Church. The church ministry weaves spiritual care and holistic care of community needs. In this way, the intervention fits the framework of public pastoral care. Our area of focus for reflection is poverty and its inhibiting features to church members and the rest of the community.

\section{Church and community mobilisation process approach and methodology Church and community mobilisation process approach}

Church and community mobilisation process is a development approach that aims to awaken the church to know and perform its role in the community. Scott et al. (2014:2) explained that 'CCMP is an expression of integral mission, which is the work of the church in contributing to the positive physical, spiritual, economic, psychological and social transformation of people'. The process provides tools for the community to be able to meet their needs using mainly locally available resources. Church and community mobilisation process builds the capacity of local churches and communities to be able to carry out their own development (Njelango 2012:v). The CCMP approach is 
Tearfund's ${ }^{1}$ development approach (Boele 2018:39-40). The CCMP process challenges traditional 'top-down' development approaches, where resources are handed down, to focus on a 'bottom-up' approach that empowers churches and communities to take ownership for the changes they want to see and to make a start using their own resources (Boele 2018:39-41). Tearfund (2017:3) explained that CCMP grew out of Tearfund's Participatory Evaluation Process (PEP). It is an approach within a wider strategy of church and community transformation whereby people are enabled to describe their reality and transform it themselves by designing their own strategies to address their own issues. The process is led by specially trained facilitators.

The objective of CCMP 'is to empower people to transform their situation using their own God-given resources in a sustainable and holistic way' (Tearfund 2017:3).

Church and community mobilisation process implementation follows five stages. The first stage entails awakening the church, which entails making the local church aware and understand its biblical mandate for holistic ministry. This will lead the church to begin to apply the biblical principles of being 'salt and light' in the community. The second stage focusses on helping people to 'read' into their reality and desire to transform it themselves, using the resources available to them. The third stage focusses on helping the church and community to have accurate information that clearly describes their situation and analysis of this information to help them make informed decisions. The fourth stage entails having a church and community that deeply understands their situation and are motivated to transform it positively and holistically. The fifth stage is about the church and community making informed decisions that, if implemented, will cause their situation to be transformed in a holistic and God honouring manner (Tearfund 2017:8).

Church and community mobilisation process involves mobilising a local church to act as a facilitator in mobilising the whole community to address their own needs by using its own resources. Church and community mobilisation process as a church development approach has been widely studied (Scott et al. 2014) and in the last 10 years it has been a subject of analysis in church-driven development studies (Boele 2018; Danladi 2011; Njelango 2012).

\section{The Anglican Church and Community Mobilisation Process project in Lesotho and study methodology}

The Lesotho Anglican Bishop was introduced to the CCMP approach in 2012 and thereafter visited Tanzania for further exposure. The Bishop embraced CCMP and introduced it to his diocese. He invited a specialist on the approach to 'envision and introduce' the basics of CCMP to the diocese

1.Tearfund is a Christian charity that helps communities overcome the worst effects of poverty and disasters. The charity works alongside local churches and other locally based organisations in over 50 countries to help people realise their plans for better future (https://www.tearfund.org). leadership. The parish leaders, namely, the clergy, agreed to implement the programme. The Bishop and the clergy selected the poorest parishes as sites of implementation. There were little or no development projects that were being implemented in the parishes that were selected. They selected a total of five parishes. One person per each parish was trained to lead CCMP implementation. The five trained individuals introduced CCMP in their parishes. The activities were effectively done from 2013 to 2016. The diocese leadership understood CCMP well before implementation, which ensured their support throughout CCMP implementation. The period 2013-2016 concentrated on the actual CCMP roll-out, particularly the training of facilitators, and in turn the facilitators implemented the agreed plans and initiatives in their parishes. The eight CCMP training workshops and their practical implementation were covered during this period.

The CCMP constituted a church-driven development initiative in poor communities being led by parish leaders as part of their pastoral ministry duties. The project was implemented not necessarily as an academic research project. However, the establishment merits analysis from a practical inquiry perspective as an implementation research. A practical inquiry approach is rooted in pragmatist philosophy. It aims at generating knowledge for local people as well as general practice (Göran n.d). Similar studies that are implemented as projects but are examined from a practical inquiry approach have been conducted in other countries and regions, including East Africa and Zimbabwe (Magezi 2017, 2018).

A cross-sectional qualitative assessment study of the CCMP programme was conducted in 2016. The study was requested by the Anglican Church through Hope Africa ${ }^{2}$ which approved the study in April 2016 as part of its documentation process to be published. Participants' consent to participate in the in-depth interviews and focus group discussions (FGDs) was voluntary. Data were collected through documents review, in-depth interviews and FGDs. The documents reviewed included project proposals, project plans, training records, progress reports, administrative records and field reports. A total number of 10 in-depth interviews (i.e. two per parish) were held with facilitators and parish leaders and five FGDs were held with church and community members who participated in integrated church and community activities (one FGD per parish of $12-15$ people). The interview questions and FGD discussions focused on how the CCMP is being implemented particularly the relationship between church and community, the interrelationships between church members and community people who are non-church members, achievements, challenges experienced whilst implementing the activities that target church members (Christians) and non-Christian community members. The participants were selected based on exposure and participation in the programme. For instance, only 2.http://www.hopeafrica.org.za/. 
individuals who had participated were invited to participate in the interviews and FGDs. The interviews and FGDs were conducted in Sotho by native Sotho speakers. The interviews were transcribed and translated into English. Data analysis was done through thematic coding.

\section{Findings and discussion Findings}

\section{Positives and promising aspects}

The effects of CCMP that showed promise and strength included the intervention's ability to change church and community people's thinking (mindset), focusing on holistic empowerment, improvement of church internal ministries (financial situation and care for one another), ability to foster church and community joining of hands, innovative thinking in addressing community problems and practical transformation of both the church (internally) and community social issues.

The introduction of CCMP assisted the parishes and parish leaders to have a framework to address challenges affecting church and community members. The church members had crippling mindset and attitude towards their poverty situation. They viewed themselves as lacking capacity to change their situation, hence they focused on getting donations from external sources. Their thinking was also in 'silo mentality' where they would go to church to attend church services (i.e. spiritual nourishment) without thinking about how the church as a community of people and structure could be leveraged as a space for spiritual and physical resources. The FGD members who were awakened and participated in activities confessed that:

We used to come to church with our minds just on praying and we would go around the deep holes on our road. But now we mobilized ourselves with community people to close the holes. It didn't require money at all to do that. (FGD 4)

The CCMP holistically empowered people. People were 'empowered mentally, spiritually and physically through gaining life skills' (In-depth interview 3). The CCMP interventions changed people's mindset about poverty. Spiritually, CCMP improved their skills to read, understand and apply the Bible in their lives. People are now able to meaningfully apply the Bible in their lives to address the situations affecting them. Furthermore, the church activities greatly assisted people to change their mindsets regarding poverty and assistance. People are now aware that they can do something to address their challenges. People can now identify their problems and then equally proceed to identify their available resources to address the situation. A facilitator explained that:

CCMP has caused a paradigm shift in us. As Sotho people we used to rely on external donations or government support. But now we have changed that mindset. We learnt that we can do things for ourselves. And we are doing it. (In-depth interview 1)
Physically, people were assisted to start initiatives both as a group and in their individual homes to address physical needs. At one parish, a church building was constructed in a short period by church members without external assistance. At the same church, the church and community members were also renovating a community road.

As the programme focused on addressing the various community challenges and changing people's mindset, church members' attitude towards financial contributions positively changed. The CCMP Bible studies challenged members to increase their Sunday collections. The FGD members at one Parish reported that CCMP has increased financial contribution of the parish. The Priest, Warden and Treasurer reported:

Here, we used to collect about R100 offering during or Sunday morning services, but because of CCMP training and awareness, we are now collecting about R600 every Sunday. (FGD 3)

Further to increased contributions, the CCMP strengthened the spirit of care amongst Christians. The notion of church as a caring community improved. CCMP gave impetus to caring ministry at the parishes through increased parcel collections and providing food handouts to old people. Through focusing on real community needs, the church members changed their attention from internal church politics and fights to focus on community needs, which brought unity. 'CCMP encourages people to come and do things together. It makes people united'. (FGD 1)

The CCMP activities assisted church members and community members to work together to address their community challenges. By focusing on church and community common challenges, the activities broke down the barrier and perception that church buildings are 'no go' areas and church people should not associate with community people. At two parishes, the church and community members worked together to construct roads. At another church, the church building 'was roofed by church members with assistance from community members after over 10 years of very slow progress' (In-depth interview 9). Therefore, CCMP 'helped people to overcome poverty of mind by thinking positively and creatively' (In-depth interview 9)about how to use available resources to address problems. It also helped the church to creatively connect and integrate with the community. One facilitator summed the situation thus:

There is evidence from the parish that CCMP gives people the ability to mobilise the community for a common cause as we saw from the construction of a road. (In-depth interview 8)

Church and community mobilisation process invested in church members to develop Bible study skills in order for people to practically apply the Bible in their lives. Whilst the focus of Bible studies was on CCMP as part of the intervention process, more Bible studies were started within churches. The Bible studies are helping people to cope with their practical life challenges through applying the Bible. One priest testified that: 
Instead of people waiting for the priest to preach on Sunday, members are now able to share the Word of God with other people through Bible studies. This has strengthened the way people look at the Bible and their lives. (In-depth interview 10)

Furthermore, CCMP changed people's behaviour regarding their devotion and commitment to the Christian faith and to one another. These changes were evident amongst Christians. However, apart from physical constructions such as road construction and material contributions, there were evident changes in the community that were attributed to CCMP. An FGD at one parish reported reduction in alcohol consumption. The FGD members observed that:

There is less alcohol being consumed now since CCMP activities started. Even at family level Christians have improved in modelling Christ's behaviour. (FGD 5)

\section{Challenges of church and community mobilisation process}

Despite the evident positive effects of CCMP, numerous challenges were reported as churches engaged in community development and forged links with communities. Bridging the church and community divide entailed overcoming multiple challenges. At the same time, by engaging in intentional development initiatives, the churches and its leadership were stretched beyond their capacity. The CCMP challenges could be classified into five categories, namely, leadership, facilitator related, CCMP implementation within the parishes, CCMP approach and CCMP adaptation.

The leadership challenges in some instances included weak support from top diocese leadership. At the same time, there was prioritisation tension that is reminiscent of the old 'duality' and 'primacy' debate, which played itself in CCMP as 'what should the church devote more time to, community mobilisation or other church spiritual activities?'. One priest explained this dilemma clearly as follows:

The church policy and practice of constant transfer of priests from one parish to another regardless of project initiatives at the parishes they are serving weakens CCMP. You lose a visionary and hardworking Priest and when you try to raise the issue you are told that it is church policy. (In-depth interview 6)

Thus, the spiritual and practical divide was also covertly evident.

By congregations assuming an explicit stance on CCMP to address poverty challenges, this resulted in expectation for increased financial contribution by leadership. The increased expectation for financial contribution by parishes implementing CCMP suggested limited in-depth understanding of the approach resulting in misperception that churches implementing it will generate quick additional resources (financial income).

The CCMP facilitator related challenges included general attrition of young facilitators because of resignation as they migrated to bigger cities to seek employment opportunities. 'The youth are seeking employment, hence they can't stay in the community to do CCMP' (FGD 1). As CCMP was integrated within the church, some facilitators had other church and family commitments, which resulted in neglecting it. One FGD echoed that:

Much as we expect the facilitator to be present and lead sessions all the time, but they also have family commitments to attend to. Sometimes they can have a family challenge or other commitment and they fail to attend. (FDG 4)

The detailed systematic step-by-step implementation process of CCMP requires some advanced training which resulted in sluggish implementation by some facilitators. The trained facilitators were also overloaded with responsibilities resulting in failing to fulfil their roles effectively. Their time was divided between church activities and their own family and home needs.

Noted also was that the manner CCMP was being implemented in parishes was skewed towards emphasising on church members. The facilitators tended to largely focus their activities and attention on church members whilst marginalising community members who are non-church members. It was also difficult to expect non-Christians to participate in Bible studies without persuading them to be Christians, which could be construed as proselytisation.

\section{Discussion}

The challenge of people perceiving their situation as hopeless, particularly poor people, is crippling. Despite structural factors of poverty, there are many studies that have shown a connection between persisting poverty and state of mind (Badger 2017). The focus of the church as an agent of change to change people's thinking regarding spiritual and physical domains of their life is critical. This avoids an overemphasis on the 'life after' at the expense of 'here and now'. The focus of the church on public needs of individual members and the community gives impetus to Christian ministry. It gives purpose and meaning to Christians. This hope and purpose translates to internal church membership enrichment as well as positioning the church as a 'real' institution in the world that understands people's lives. Church and community interventions reduced the barrier between church and community. This resulted in the church and community engaging in public projects. As the church takes a lead in facilitating development, it leverages on its community setting (situation), its faith motivation, community leadership, membership as its critical resource and community agency. By shifting to engage in public issues, the church demonstrates a caring heart and concern for its members. This concern extrapolates to the rest of the community because church members are from the same community. When the church is viewed as a spiritual beacon and at the same time viewed as a caring structure of a struggling society (Magezi 2007), it becomes inevitable for it to address social challenges. For instance, it is evident from the CCMP interventions that the same road used by community members is the same road that the pastor drives through and yet no one used to care about fixing it. How can a community fail to see and act on such an obvious issue? In this sense, public pastoral care is to see and join hands with 
the community. It entails breathing the same air and being affected by same issues as the community and then being driven to action. This is an organic process.

Public focus of the church, which is evident from CCMP approach, revealed that by focusing on practical community challenges church members indirectly enrich themselves as well. The public role of the church helps it to develop a 'human heart', refocus and re-examine itself. Church and community mobilisation process increased care ministry whilst at the same time addressing community physical challenges. Public pastoral care is about congregational care, a kind of church care that discourages church and Christianity to be an abstract concept with no relevance to people (Levesque 2014; Mannion 2009). As Vanhoozer and Strachan (2015) explained, this entails the pastor being a public theologian who is called to point or direct people, to nurture and facilitate church people to live their true identity both within and without. Thus, pastoral care tackles life and its intertwined challenges in all its spheres. Church and community mobilisation process made the church 'real' in the world but with a clear understanding of the transient nature of life as well (Jn 17:14-18). People received parcels (physical help) and yet Bible studies (spiritual care) provided a soothing of the heart also. The interventions revealed that spiritual needs exist alongside physical needs. As people address physical needs, their spiritual needs get addressed as well. Community planning and interventions also led to improved spiritual care through effective Bible studies and application of the Bible in people's lives. Notably also, the presence of Christianity in a community where the church approach has an intentional public ministry positively correlated with positive social change in things such as reduction of alcoholism.

However, as churches engaged in diverse community challenges, it was evident that CCMP was considered some kind of a special ministry, a sort of development intervention that is slightly separate from other church ministries. This resulted in raising expectations beyond the capacities of the parishes. It is a standing challenge that as churches start to design special holistic ministries with an intentional public dimension, certain expectations arise. The challenge is to make such ministries deeply rooted in congregational ministry activities.

Church and community mobilisation process revealed that whilst church and community interventions are considered the ideal way of doing Christian ministry (integral mission), the challenge of duality and primacy, that is, what takes precedent between spiritual and physical issues, remains a challenge in practice. Church and community mobilisation process needs seemed to be overridden by preference to spiritual needs. Church and community mobilisation process also revealed that Christian development requires attention. As the church engages in various church ministries, the pastor gets pulled in different directions. As a result, the pastor relies on teams of volunteers who have their own family and home priorities as well. Straddling between spiritual and development work stretches the pastor beyond his or her limits. This poses a risk of leaving other things undone.

Therefore, making strategic choices on the issues to engage is critical, which Greider (2008:54) referred to as choice on what to triage.

The CCMP interventions also revealed the persisting challenge of balance between churches serving their members and excluding other community people. Balancing this tension is a difficult challenge to resolve in church-driven development initiatives. The CCMP demonstrated in detail how churches tend to prefer and prioritise their members. James (2009) rightly observed that church-related NGOs and churches tend to benefit church members more and exclude outside people. The tension is between doing good especially to those who belong to the family of believers in the church and fair treatment and equitable allocation of resources to the rest of the community (Galatians 6:10).

\section{Conclusion}

The shift of pastoral care to public theology, which renders it public pastoral care, is timely, particularly in view of the challenges being experienced in communities. The persisting challenge, however, is that the discussion in many cases tends to be theoretical, with little demonstration of how pastoral care can take a public dimension.

Evident from our discussion is that public pastoral care, particularly in African contexts, cannot revolve around the person of the pastor. In the first instance, because of prevailing poverty and many other public needs, public pastoral care is not an option but an imperative congregational ministry. Secondly, it should assume a congregational approach. A caregiver has to choose the issues to address amongst the many challenges. Often these challenges are intertwined and thus require interventions at multiple levels. As a pastor or a congregation engages in such issues, a model such as CCMP provides insights into how one may proceed by focusing on local context with needs determined by the local church and community people. Thus, triaging in public pastoral care calls for a strong contextual approach. And in attending to do the many public challenges, public pastoral care does not take a straight or linear approach but a spiral process that is systemic. In doing so, public pastoral care inevitably intertwines with community development and the ensuing complexities associated with community development. And yet, in all these issues, at the heart of pastoral care is the holistic care and concern of people.

\section{Acknowledgements}

The author would like to thank Hope Africa for the invitation, support and permission to use the case study of its work. 


\section{Competing interests}

The author declares that they have no financial or personal relationships which may have inappropriately influenced them in writing this article.

\section{Author's contributions}

V.M. is the sole contributor to this research article.

\section{Ethical considerations}

This article followed all ethical standards for a research without direct contact with human or animal subjects.

\section{Funding information}

This research received no specific grant from any funding agency in the public, commercial, or not-for-profit sectors.

\section{Data availability statement}

Data sharing is not applicable to this article as no new data were created or analysed in this study.

\section{Disclaimer}

The views and opinions expressed in this article are those of the authors and do not necessarily reflect the official policy or position of any affiliated agency of the authors.

\section{References}

Ashby, H.U., 2000, 'Pastoral theology as public theology: Participating in the healing of damaged and damaging cultures and institutions', Journal of Pastoral Theology 10(1), 18-27. https://doi.org/10.1179/jpt.2000.10.1.003

Bader, R., 2015, The African challenges to the church, viewed 18 February 2019, from https://www.lastampa.it/2015/11/30/vaticaninsider/the-african-challenges-tothe-church-1BnvVXkYLC7uGy9HAK4oMJ/pagina.html.

Badger, E., 2017, Does 'wrong mind-set' cause poverty or vice versa? viewed 12 March 2019, from https://www.nytimes.com/2017/05/30/upshot/ben-carsons-thinkingand-how-poverty-affects-your-state-of-mind.htm

Bediako, K., 1997, 'African theology', in D. Ford (ed.), The Modern theologians, pp. 426-444, Basil Blackwell, Cambridge, MA.

Boele, E., 2018, 'Church and community mobilisation: Analysing inclusion and empowerment of socially marginalized people in villages in Northern Tanzania', MS dissertation in International Development Studies, Wageningen UR, the Netherlands.

Chester, T., 2004, Good news to the poor: Social involvement and the Gospel, Intervarsity Press, Nottingham.

Chimhanda, H.F., 2010, 'Black theology of South Africa and the liberation paradigm', Scriptura 105(2010), 434-445. https://doi.org/10.7833/105-0-163

Danladi, M., 2011, Church and Community Mobilisation (CCM) experiences in Nigeria viewed 05 March 2019, from https://docplayer.net/30966917-Church-andcommunity-mobilisation-ccm-experiences-in-nigeria.html.

Day, K. \& Sebastian, K., 2017, 'Introduction', in S. Kim \& K. Day (eds.), A companion to public theology, pp. 1-21, 40-66, Brill publishers, Leiden.

De Gruchy, J., 2007, 'Public theology as Christian witness: Exploring the genre' International Journal of Public Theology 1(1), 26-41. https://doi.org/10.1163/ $156973207 X 194466$

De Villiers, E., 2005, 'The vocation of reformed ethicist in the present South African society', Scriptura 89(2), 521-535. https://doi.org/10.7833/89-0-1035

Dreyer, J.S., 2011, 'Public theology and the translation imperative: A Ricoeurian perspective', HTS Teologiese Studies/Theology 67(3), Art. \#1157. https://doi. org/10.4102/hts.v67i3.1157

Dreyer, J.S. \& Pieterse, H.J.C., 2010, 'Religion in the public sphere: What can public theology learn from Habermas's latest work?', HTS Teologiese Studies/Theological Studies 66(1), Art. \#798. https://doi.org/10.4102/hts.v66i1.798

Dreyer, Y., 2004, 'A public practical theological theory for religious education of secularised youth', HTS Teologiese Studies/Theological Studies 60(3), 919-945. https://doi.org/10.4102/hts.v60i3.615
Göran, G., n.d., 'Practical inquiry as action research and beyond', in 16th European Conference on Information Systems, viewed 01 September 2017, from https:// pdfs.semanticscholar.org/0b1f/3a43d914b654b49c3a0620f5e9aa30d44d67.pdf.

Graham, L.K., 2000, 'Pastoral theology as public theology in relation to the clinic', Journal of Pastoral Theology 10(1), 1-17. https://doi.org/10.1179/jpt.2000.10.1.002

Greider, K.J., 2008, 'Pedagogy in practical theology: Two problems in the case of pastoral care', International Journal of Practical Theology 12, 52-58.

James, R., 2009, Faith-Based Organisational Development (OD) with churches in Malawi, Praxis Note No. 47, International NGO Training and Research Centre, viewed 12 March 2019, from https://www.intrac.org/wpcms/wp-content/ uploads/2016/09/Praxis-Note-47-Faith-Based-Organisational-Development-withChurches-in-Malawi-Rick-James-with-CABUNGO-staff.pdf.

Kim, S., 2017, 'Public theology in the History of Christianity', in K. Sebastian \& K. Day (eds.), A companion to public theology, pp. 40-66, Brill Publishers, Leiden.

Koppel, M.S., 2015, 'Practicing public pastoral theologies in contexts of difference', Journal of Pastoral Theology 25(3), 151-152. https://doi.org/10.1080/10649867. 2015.1123923

Koopman, N., 2012, 'Public theology in pluralistic societies? Lessons from the theology of Etienne de Villiers', Verbum et Ecclesia 33(2), Art. \#773, 6 pages. https://doi. org/10.4102/ve.v33i2.773

Leslie, K.J., 2008, 'Pastoral care in a new public: Lessons learned in the public square', Journal of Pastoral Theology 18(2), 80-99. https://doi.org/10.1179/jpt.2008. 18.2.005

Levesque, M.R. 2014, 'Political theology versus public theology: Reclaiming the heart of Christian mission', Masters of Arts dissertation, The University of Western Ontario, London, Ontario.

Louw, D.J., 2014, Wholeness in hope care on nurturing the beauty of the Human sou in spiritual healing, LIT, Wien.

Magezi, V., 2007, HIV and AIDS, poverty and pastoral care and counselling: A homebased and congregational systems ministerial approach in Africa, Sun Media, Stellenbosch.

Magezi, V., 2016, 'Reflection on pastoral care in Africa: Towards discerning emerging pragmatic pastoral ministerial responses', In die Skriflig 50(1), a2130. https://doi. org/10.4102/ids.v50i1.2130

Magezi, V., 2017, 'Making community development at grassroots reality: Churchdriven development approach in Zimbabwe's context of severe poverty', In die Skriflig 51(1), a2263. https://doi.org/10.4102/ids.v51i1.2263

Magezi, V., 2018, 'Church-driven primary health care: Models for an integrated church and community primary health care in Africa (a case study of the Salvation Army in East Africa)', HTS Teologiese Studies/Theological Studies 74(2), 4365. https:// doi.org/10.4102/hts.v74i2.4365

Magezi, V. \& Mutowa, C., 2018, 'Towards doing practical integral mission: A Nazarene Compassionate Ministries (NCM) reflection in Africa', Acta Theologica 38(2), 123-144. https://doi.org/10.18820/23099089/actat.v38i2.8

Mannion, G., 2009, 'A brief genealogy of public theology, or doing theology when it seems nobody is listening', Annali distudi Religiosi 10, 121-154.

Mati, J.M., 2013., Bringing back 'faith' in discourses of African Civil society: Views from a convening in Nairobi, ISTR Africa Network Regional Conference, Nairobi, July 2013, pp. 11-13, viewed 20 January 2017, from http://c.ymcdn.com/sites/www. istr.org/resource/resmgr/africa2013/bringing_back_faith_in_disco.pdf.

McClure, B., 2012, 'Pastoral care', in Miller-McLemore, B.J. (ed.), The Wiley-Blackwell companion to practical theology, pp. 269-278, Blackwell Publishing Ltd, Chichester.

Miller-McLemore, B.J., 2004, 'Pastoral theology as public theology: Revolutions in the 'Fourth area', in N.J. Ramsay (ed.), Pastoral care and counseling: Redefining the paradigms, pp. 45-64, Abingdon, Nashville, TN.

Miller-McLemore, B.J., 2005, 'Pastoral theology and public theology', in E. Graham \& A. Rowlands (eds.), Pathways to the public square: Practical theology in an age of pluralism, pp. 95-105, Lit Verlag, Munster.

Miller-McLemore, B.J., 2018, 'The living human web: A twenty-five year retrospective', Pastoral Psychology 67, 305-321. https://doi.org/10.1007/ s11089-018-0811-7

Mo Ibrahim Foundation, 2018, Ibrahim index of African governance, 2018 Index Report viewed 10 February 2019, from http://s.mo.ibrahim.foundation/u/2018/ 11/27173840/2018-Index-Report.pdf?_ga=2.121704898.857418585.15503183181896488062.1550318318

Moseley, R.M., 1990, 'Liberation theology and pastoral care', in R.J. Hunter (ed.), Dictionary of pastoral counseling and care, pp. 645-647, Abingdon, Nashville, TN.

Mugambi, J.N.K., 1995, From liberation to reconstruction, East Africa Educationa Publishers, Nairobi.

Mugambi, J.N.K., 2003, Christian theology and social reconstruction, Acton Press, Nairobi.

NetACT, 2018, African public theology, viewed 11 February 2019, from http://netact. christians.co.za/wp-content/uploads/sites/6/2019/01/AFRICAN-PUBLIC THEOLOGY-project-description-for-wbsite-Jan-2019.pdf.

Njelango, J., 2012, 'Church and community mobilisation process return on investment tracking system/tools - The case of Tanzania, Kenya, Uganda, Sudan and South Sudan', PhD thesis compilation submitted to Global University for Lifelong Learning (GULL), CA.

Nwachuku, D.N., 2014., 'Practical theology in West Africa', in B.J. Miller-McLemore (ed.), The Wiley-Blackwell companion to practical theology, pp. 515-524, WileyBlackwell, Oxford. 
Osmer, R. \& Schweitzer, F., 2003, Religious education between modernization and globalization: New perspectives on the United States and Germany, Eerdmans, Grand Rapids, MI.

Peters, D.H., Taghreed, A., Olakunle, A., Akua, A.I. \& Nhan, T., 2014, 'Implementation research: What it is and how to do it', Journal of Sports Medicine 48, 731-736. https://doi.org/10.1136/bmj.f6753

Ramsay, N.J., 2004, 'A time of ferment and redefinition', in N.J. Ramsay (ed.), Pastoral care and counseling: Redefining the paradigms, pp. 1-43, Abingdon Press, Nashville, TN.

Ramsay, N.J., 2014, 'Intersectionality: A model for addressing the complexity of oppression and privilege', Pastoral Psychology 63, 453-469. https://doi.org/10. 1007/s11089-013-0570-4

Scott, N., Foley, A., Dejean, C., Brooks, A. \& Batchelor, S., 2014, An evidence-based study of the impact of church and community mobilisation in Tanzania, Tearfund and Gamos, London.

Stevenson, C., 2005, 'Practical inquiry/theory in nursing', Journal of Advanced Nursing 50, 196-203. https://doi.org/10.1111/j.1365-2648.2005.03379.x
Sugden, C., 2010, 'Mission as transformation - Its journey among Evangelicals since Lausanne 1', in B. Woolnough \& W. Ma (eds.), Holistic mission: God's plan for God's people, pp. 31-36, Regnum Books International, Oxford.

Tearfund, 2017, Church and community mobilisation in Africa, Teafund, Teddington.

Tracy, D., 1981, The analogical imagination: Christian theology and the culture of pluralism, Crossroads Publishing Co, New York.

Transparency International, 2018, Corruption perceptions index 2017, viewed 16 February 2019, from https://www.transparency.org/news/feature/corruption perceptions_index_2017.

Vanhoozer, K.J. \& Strachan, O., 2015, The pastor as public theologian: Reclaiming a lost vision, Baker Academic books, MI.

Villa-Vicencio, C., 1992, A theology of reconstruction: Nation building and rights, Cambridge University Press, Cambridge.

Woolsey, K. \& Biebel, K., 2007, Implementation research: The black box of program implementation, viewed 01 September 2018, from https://www.umassmed.edu/ globalassets/center-for-mental-health-services-research/documents/productspublications/issue-briefs/rehab/. 